\title{
Kajian Ekonomi Pariwisata Syariah Kota Banda Aceh
}

\author{
Nanda Rahmi \\ Fakultas Ekonomi dan Bisnis, Universitas Syiah Kuala \\ e-mail: nanda_rahmi84@unsyiah.ac.id
}

\begin{abstract}
Abstrak
Kota Banda Aceh adalah ibukota Provinsi Aceh yang merupakan salah satu daerah yang memberlakukan Syariat Islam di Indonesia. Kota Banda Aceh juga mengalami dampak yang besar saat bencana Tsunami menghancurkan tanah Aceh pada tahun 2004 lalu. Walau pernah mengalami bencana besar, kini Kota Banda Aceh kembali berbenah diri untuk menjadi tempat destinasi pariwisata berbasis syariah dengan mengandalkan kawasan pariwisata, adat istiadat, dan budaya.Pengembangan sektor pariwisata Kota Banda Aceh dilakukan berdasarkan pada nilai-nilai Islam. Sektor pariwisata ini diharapkan menjadi sektor utama yang mampu mendorong pertumbuhan ekonomi daerah. Peningkatan jumlah kunjungan pariwisata menjadi faktor pendukung terjadinya peningkatan infrastruktur dan sarana pendukung lainnya sehingga sektor pariwisata mampu menjadi sektor utama terhadap peningkatan perekonomian daerah. Peningkatan ini dapat dilihat dari peningkatan subsektor hotel, restoran, dan biro perjalanan wisata. Peningkatan perekonomian ini juga tampak dari peningkatan kontribusi sektor pariwisata terhadap perekonomian Banda Aceh.
\end{abstract}

Kata Kunci : wisata syariah, Banda Aceh, ekonomi, pertumbuhan

\section{PENDAHULUAN}

Sektor pariwisata merupakan salah satu sektor potensial yang sedang serius dikembangkan saat ini, yang bertujuan untuk menjadi salah satu sumber pendapatan daerah. Secara luas pariwisata dipandang sebagai kegiatan multidimensi dari rangkaian suatu proses pembangunan. Pembangunan sektor pariwisata menyangkut aspek sosial budaya, ekonomi dan politik (Spillane, 1994 : 14). Dalam Undang-undang Nomor 10 tahun 2009 tentang kepariwisataan, menyatakan bahwa penyelenggaraan kepariwisataan ditujukan untuk meningkatkan pendapatan nasional dalam rangka meningkatkan kesejahteraan dan kemakmuran rakyat, memperluas dan memeratakan kesempatan berusaha dan lapangan kerja, mendorong pembangunan daerah, memperkenalkan dan mendayagunakan objek dan daya tarik wisata di Indonesia serta memupuk rasa cinta tanah air dan mempererat persahabatan antar bangsa.
Kondisi parwisata Indonesia pada tahun 2015 secara makro menunjukkan perkembangan dan kontribusi yang terus meningkat dan semakin signifikan terhadap PDBnasional sebesar $4,23 \%$ atau senilai 461,36 trilyun, dengan peningkatan devisa yang dihasilkan mencapai US\$ 11,9 milyar, dan tenaga kerja pariwisata sebanyak 12,16 juta. Pada kondisi mikro, juga ditandai dengan peningkatan jumlah wisatawan macanegara dan domestik. Salah satu indicator penting yang menjadi patokan adalah aspek daya saing kepariwisataan, dimana posisi Indonesia meningkat sigifikan dari peringkat 70 dunia menjadi rangking 50 di tahun 2015 (Kemenpar, 2015).

Seiring perkembangan sektor pariwisata secara umum, konsep pariwisata syariah dewasa ini telah menjadi tren dalam pengembangan ekonomi yang berbasis pariwisata di beberapa tempat. Konsep ini meliputi adat istiadat dan budaya yang berlandaskan nilai-nilai Islam, gaya hidup 
sehingga produk-produk dengan konsep halal.Definisi Pariwisata syariah adalah kegiatan yang didukung oleh berbagai fasilitas layanan yang disediakan masyarakat, pengusaha, pemerintah, dan pemerintah daerah yang memenuhi ketentuan syariah (Kemenpar, 2012).

Keberadaan pariwisata syariah dapat menyokong pertumbuhan ekonomi dengan menghidupkan industri kreatif masyarakat. Cohen (1984, dalam Pitana, 2006) mengelompokkan dampak pariwisata secara umum terhadap kondisi ekonomi dan sosial masyarakat setempat, menjadi delapan kelompok besar, yaitu (1) dampak terhadap penerimaan devisa, (2) dampak terhadap pendapatan masyarakat, (3) dampak terhadap kesempatan kerja, (4) dampak terhadap harga-harga, (5) dampak terhadap distribusi masyarakat, (6) dampak terhadap kepemilikan, (7) dampak terhadap pembangunan secara umum, dan (8) dampak terhadap pendapatan pemerintah.

Keberhasilan sektor pariwisata suatu daerah sangat tergantung pada jumlah kunjungan wisatawan ke daerah tersebut. Merujuk pada penerapan konsep pariwisata syariah, keberadaan wisatawan terus meningkat. Dalam State of the Global Islamic Economy 2013 Report disebutkan nilai pariwisata syariah sama dengan 12,5 persen dari keseluruhan nilai belanja pariwisata dunia, dan belum termasuk didalamnya pengeluaran untuk umrah dan haji. Sebuah studi lainnya yang dilakukan oleh Mastercard dan CrescentRating (2015) dalam Global Muslim Travel Index (GMTI) 2015, menyebutkan bahwa pada tahun 2014 terdapat 108 juta wisatawan muslim yang memiliki nilai pengeluaran US\$145 miliar. Jumlah ini diperkirakan akan terus meningkat seiring perkembangan industri syariah dan diprediksi memberikan dampak positif terhadap perekonomian masyarakat.

Didasari keadaan tersebut, Kementerian Pariwisata Republik Indonesia menetapkan tiga belas provinsi tujuan wisata yang memiliki potensi sebagai kawasan wisata syariah di Indonesia. Tiga belas daerah tersebut adalah Nusa Tenggara Barat (NTB), Aceh, Sumatera Barat, Riau, Lampung, Banten, DKI Jakarta, Jawa Barat, Jawa Tengah, Yogyakarta, Jawa Timur, Sulawesi Selatan, dan Bali (IndonesiaTravel, 2013). Setiap daerah tersebut ditetapkan dengan standarisasi syariah di tiga sektor wisata yaitu restoran, hotel dan biro perjalanan wisata (Kemenpar, 2014). Standarisasi tersebut memenuhi kriteria-kriteria yang berbeda dengan konsep pariwisata lainnya, dapat di lihat di tabel 1. perbandingan antara konsep wisata syariah dengan konsep wisata lainnya.

Kota Banda Aceh adalah ibukota Provinsi Aceh yang merupakan salah satu daerah yang memberlakukan Syariat Islam di Indonesia. Kota Banda Aceh juga mengalami dampak yang besar saat bencana Tsunami menghancurkan tanah Aceh pada tahun 2004 lalu.

Walau pernah mengalami bencana besar, kini Kota Banda Aceh kembali berbenah diri untuk menjadi tempat destinasi pariwisata berbasis syariah dengan mengandalkan kawasan pariwisata, adat istiadat, dan budaya. Hal ini direalisasikan dengan meluncurkan branding pariwisata yaitu World Islamic Tourism pada tanggal 31 Maret 2015 (Hutabarat, 2015). Pemerintah Kota Banda Aceh mencoba menarik wisatawan dengan menawarkan konsep wisata syariah dengan didukung peningkatan sarana dan prasarana.

Indonesia saat ini merupakan Negara dengan mayoritas penduduk muslim terbesar di dunia, dengan jumlah penduduk Muslim sebesar 207.176.162 (BPS,2010). Sehingga sudah sepatutnya sektor pariwisata melihat hal ini sebagai salah satu pasar potensial, dengan menggabungkan konsep wisata dengan nilai-nilai Islam.

Pasar wisata syariah masih dianggap sebagai untapped market dimana permintaan yang ada belum mampu dipenuhi dan keberadaannya belum dimanfaatkan secara maksimal, sehingga masih memungkinkan untuk adanya penyesuaian dan inovasi . 
Tabel 1. Komparasi wisata konvensional, wisata religi, dan wisata syariah

\begin{tabular}{|c|c|c|c|c|}
\hline No & $\begin{array}{c}\text { Item } \\
\text { Perbandingan }\end{array}$ & Konvensional & Religi & Syariah \\
\hline 1 & Objek & $\begin{array}{l}\text { Alam, budaya, } \\
\text { heritage, kuliner }\end{array}$ & $\begin{array}{l}\text { Tempat ibadah, } \\
\text { peninggalan sejarah }\end{array}$ & Semuanya \\
\hline 2 & Tujuan & Menghibur & $\begin{array}{l}\text { Meningkatkan } \\
\text { spiritualitas }\end{array}$ & $\begin{array}{l}\text { Meningkatkan } \\
\text { spiritualitas dengan } \\
\text { cara menghibur }\end{array}$ \\
\hline 3 & Target & $\begin{array}{lr}\text { Menyentuh } & \\
\text { kepuasan } & \text { dan } \\
\text { kesenangan } & \text { yang } \\
\text { berdimensi } & \text { nafsu, } \\
\text { semata-mata } & \text { hanya } \\
\text { untuk hiburan } & \end{array}$ & $\begin{array}{l}\text { Aspek spiritual yang } \\
\text { bisa menenangkan jiwa. } \\
\text { Guna mencari } \\
\text { ketenangan batin }\end{array}$ & $\begin{array}{l}\text { Memenuhi keinginan } \\
\text { dan kesenangan serta } \\
\text { menumbuhkan } \\
\text { kesadaran beragama }\end{array}$ \\
\hline 4 & Guide & $\begin{array}{lr}\text { Memahami } & \text { dan } \\
\text { menguasai informasi } \\
\text { sehingga } & \text { bisa } \\
\text { menarik } & \text { wisatawan } \\
\text { terhadap } & \text { objek } \\
\text { wisata } & \end{array}$ & $\begin{array}{l}\text { Menguasai sejarah tokoh } \\
\text { dan lokasi yang menjadi } \\
\text { objek wisata }\end{array}$ & $\begin{array}{l}\text { Membuat turis tertarik } \\
\text { pada objek sekaligus } \\
\text { membangkitkan spirit } \\
\text { religi wisatawan. } \\
\text { Mampu menjelaskan } \\
\text { fungsi dan peranan } \\
\text { syariah dalam bentuk } \\
\text { kebahagiaan dan } \\
\text { kepuasan batin dalam } \\
\text { kehidupan manusia. }\end{array}$ \\
\hline 5 & Fasilitas Ibadah & Sekedar pelengkap & Sekedar pelengkap & $\begin{array}{l}\text { Menjadi bagian yang } \\
\text { menyatu dengan objek } \\
\text { pariwisata, ritual ibadah } \\
\text { menjadi bagian paket } \\
\text { hiburan }\end{array}$ \\
\hline 6 & Kuliner & Umum & Umum & Spesifik yang halal \\
\hline 7 & $\begin{array}{l}\text { Relasi dengan } \\
\text { masyarakat } \\
\text { dilingkungan } \\
\text { objek wisata }\end{array}$ & $\begin{array}{l}\text { Komplementer dan } \\
\text { hanya untuk } \\
\text { keuntungan materi }\end{array}$ & $\begin{array}{l}\text { Komplementer dan } \\
\text { hanya untuk keuntungan } \\
\text { materi }\end{array}$ & $\begin{array}{l}\text { Integrated, interaksi } \\
\text { berdasar pada prinsip } \\
\text { syariah }\end{array}$ \\
\hline 8 & $\begin{array}{l}\text { Agenda } \\
\text { Perjalanan }\end{array}$ & Setiap waktu & Waktu-waktu tertentu & Memperhatikan waktu \\
\hline
\end{tabular}

Sumber : Ngatawi Al Zaztrow dalam Hamzah dan Yudiana, 2015

\section{Pembangunan Kota Banda Aceh sebagai kawasan wisata syariah}

Industri pariwisata merupakan agenda pembangunan yang menjadi perhatian utama di seluruh dunia saat ini tidak terkecuali kawasan Asia Tenggara termasuk Indonesia, karena besarnya sumbangan atas perekonomian negara dan daerah setempat (Redzuan Othman \& Norlida Hanim, 2010). Kemajuan industri pariwisata suatu daerah sangat bergantung kepada jumlah wisatawan yang berkunjung serta ditunjang dengan peningkatan pemanfaatan Daerah Tujuan
Wisata (DTW), sehingga target dapat dicapai dari sektor tersebut.

Kota Banda Aceh merupakan daerah yang giat mengembangkan potensi pariwisatanya. Pasca Tsunami, Kota Banda Aceh kembali membangun dalam berbagai sektor dengan bantuan yang datang baik dari dalam maupun luar negeri. Hingga kini Kota Banda Aceh telah mengalami begitu banyak perubahan dimana kondisi daerah yang semakin berkembang pesat di berbagai segi, baik segi ekonomi, segi pendidikan, segi pemerintahan, dan segi pariwisata khususnya. 
Letak geografis Kota Banda Aceh berada di wilayah paling barat Pulau Sumatera, dengan posisi astronomis berada pada posisi $05^{0} 16^{\prime} 15^{\prime}$ '- $05^{0} 36^{\prime} 16^{\prime \prime}$ lintang utara dan $95^{\circ} 16^{\prime} 15^{\prime \prime}-95022^{\prime} 35^{\prime \prime}$ bujur timur, dengan luas wilayah keseluruhan $61,36 \mathrm{~km}^{2}$ dan ketinggian rata-rata 0,80 meter di atas permukaan laut (BPS, 2016). Kota Banda Aceh memiliki potensi ekonomi besar sebagai gerbang bagian barat Indonesia dan berhadapan langsung dengan Samudera Hindia. Potensi tersebut secara tidak langsung dapat menjadi aset bagi Kota Banda Aceh dalam pelaksanaan pembangunannya, khususnya dalam sektor pariwisata.

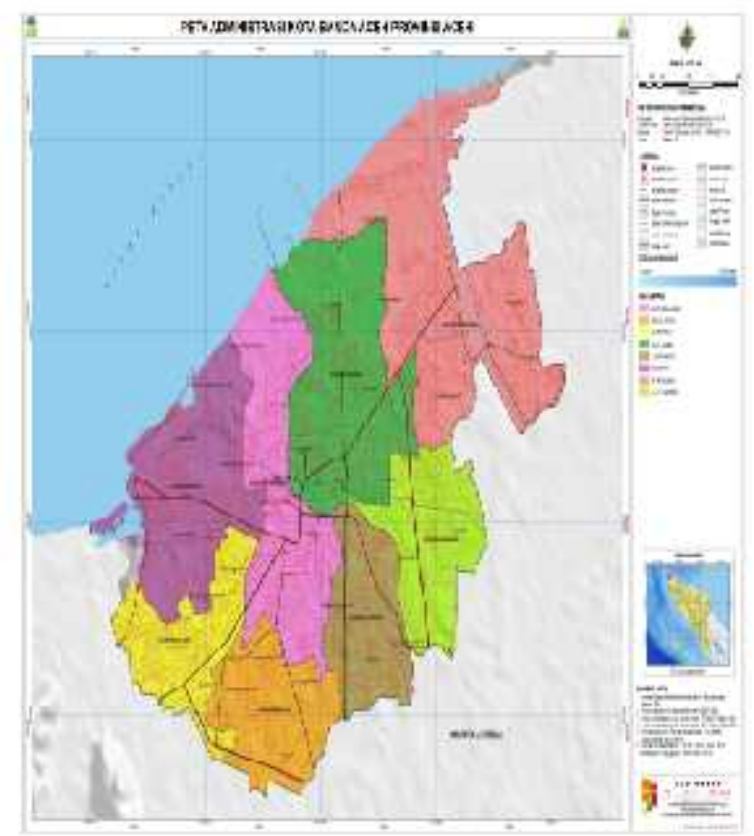

\section{Gambar 1. Peta Administrasi Kota Banda Aceh}

Kota Banda Aceh terbagi menjadi sembilan wilayah kecamatan, diantaranya kecamatan Meuraxa, Jaya Baru, Banda Raya, Baiturrahman, Lueng Bata, Kuta Alam, Kuta Raja, Syiah Kuala, dan Ulee Kareng. Berbagai objek wisata sebagai potensi wisata Banda Aceh tersebar di seluruh kecamatan. Objek wisata tersebut terdiri atas 4 lokasi objek wisata alam, 5 lokasi objek wisata Tsunami, 6 lokasi objek wisata spiritual dan bersejarah, serta 29 lokasi objek wisata sejarah dan purbakala (BPS, 2016). Seiring gencarnya pembangunan sektor wisata yang dilakukan pemerintah setempat, beberapa lokasi objek wisata tersebut kini semakin

terkenal baik oleh wisatawan domestik maupun mancanegara, seperti Masjid Raya Baiturrahman, Museum Negeri Aceh, Kher Koff, Museum Tsunami Aceh, Pantai Ulee Lheue, PLTD Apung, dan Kapal di Atas Rumah (Kemenpar, 2015).

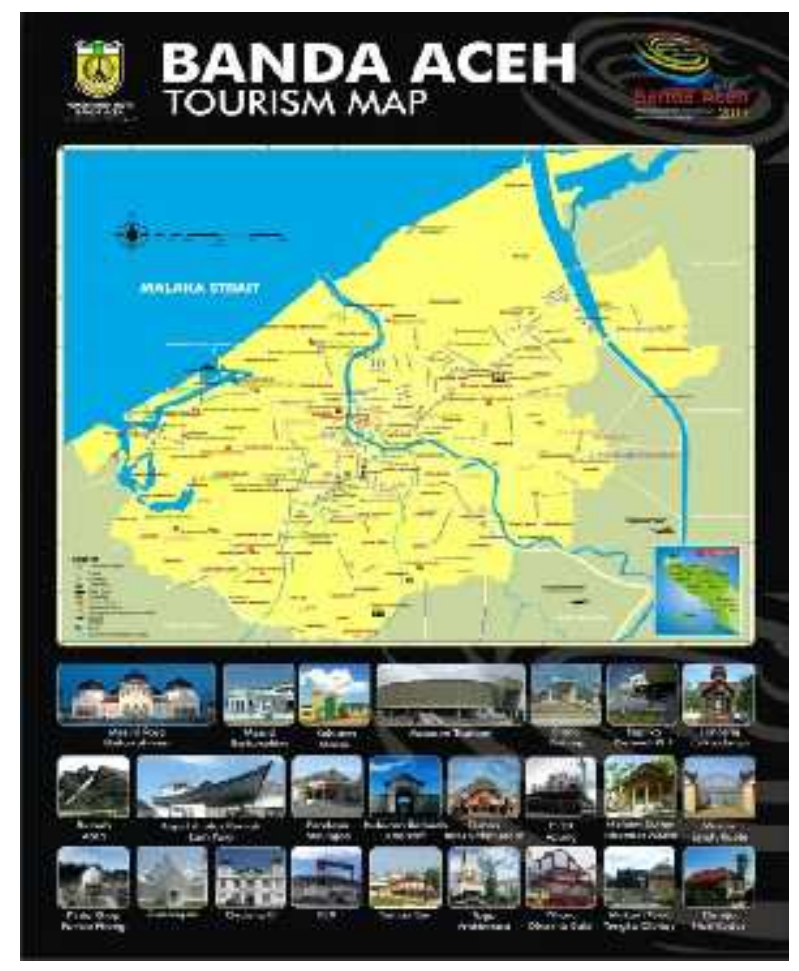

\section{Gambar 2. Sebaran Objek Wisata Kota Banda Aceh}

Pembangunan sektor pariwisata Kota Banda Aceh juga didukung dengan anggaran yang diperuntukkan bagi peningkatan potensi daerah untuk pencapaian target yang ingin dicapai di sektor tersebut. Pemerintah daerah dituntut untuk dapat menggali dan mengelola potensi pariwisata yang dimiliki dengan menggunakan anggaran yang ada sebagai usaha untuk peningkatan kualitas objek wisata yang sudah ada atau membuat suatu terobosan dengan membuat suatu objek wisata baru sehingga mendorong pertumbuhan ekonomi setempat. Dukungan anggaran yang diperuntukkan bagi pengembangan pariwisata terlihat pada besaran realisasi belanja suatu daerah. Berikut realisasi belanja daerah kota Banda Aceh menurut fungsi (Rp), 2012-2015, lihat tabel 2 
Tabel 2. Realisasi Belanja Daerah Kota Banda Aceh Menurut Fungsi (Rp), 2012-2015

\begin{tabular}{clrrrrr}
\hline No & \multicolumn{1}{c}{ Fungsi } & \multicolumn{2}{c}{$\mathbf{2 0 1 2}$} & $\mathbf{2 0 1 3}$ & $\mathbf{2 0 1 4}$ & \multicolumn{1}{c}{$\mathbf{2 0 1 5}$} \\
\hline 1 & $\begin{array}{l}\text { Pelayanan } \\
\text { Umum }\end{array}$ & 186.898 .891 .696 & 101.182 .517 .279 & 101.930 .120 .208 & 103.571 .838 .230 \\
\hline 2 & $\begin{array}{l}\text { Ketertiban dan } \\
\text { Keamanan }\end{array}$ & 10.882 .538 .643 & 5.432 .582 .958 & 10.473 .331 .504 & 8.274 .430 .940 \\
\hline 3 & Ekonomi & 38.855 .562 .362 & 30.072 .501 .282 & 41.099 .664 .030 & 47.338 .706 .580 \\
\hline 4 & $\begin{array}{l}\text { Lingkungan } \\
\text { Hidup }\end{array}$ & 37.447 .369 .516 & 34.526 .123 .939 & 42.747 .484 .462 & 54.521 .187 .157 \\
\hline 5 & $\begin{array}{l}\text { Perumahan dan } \\
\text { Fasilitas Umum }\end{array}$ & 39.777 .569 .815 & 66.125 .832 .214 & 129.180 .144 .532 & 136.242 .255 .451 \\
\hline 6 & Kesehatan & 78.901 .494 .270 & 52.277 .154 .039 & 88.642 .279 .072 & 121.991 .300 .243 \\
\hline 7 & $\begin{array}{l}\text { Pariwisata dan } \\
\text { Budaya }\end{array}$ & 9.617 .263 .067 & 9.391 .706 .801 & 9.274 .043 .181 & 8.122 .439 .086 \\
\hline 8 & Pendidikan & 340.138 .368 .807 & 46.921 .641 .192 & 67.149 .086 .755 & 73.161 .435 .306 \\
\hline 9 & $\begin{array}{l}\text { Perlindungan } \\
\text { Sosial }\end{array}$ & 22.885 .836 .936 & 10.515 .568 .083 & 9.618 .366 .887 & 9.382 .889 .707 \\
\hline & & & & \\
\hline
\end{tabular}

Sumber: BPS Kota Banda Aceh, 2016

Berdasarkan data realisasi belanja daerah Kota Banda Aceh, fungsi pariwisata dan kebudayaan mendapat alokasi anggaran yang bervariasi. Pada tahun 2012, fungsi pariwisata dan budaya mendapatkan alokasi sebesar Rp 9.617.263.067 atau sebesar 1,26\% dari total belanja daerah. Pada tahun 2013, fungsi pariwisata dan budaya mendapat alokasi sebesar Rp 9.391.706.801 atau sebesar 2,43\% dari total belanja daerah. Pada tahun 2014, fungsi pariwisata dan budaya mendapat alokasi Rp 9.274.043.181 atau sebesar 1,85\%. Pada tahun 2015, fungsi pariwisata dan budaya mendapat alokasi Rp 8.122.439.086 atau sebesar $1,44 \%$.

Alokasi anggaran bagi fungsi pariwisata dan kebudayaan dimanfaatkan untuk meningkatkan prospek kepariwisataan daerah, mendorong langkahlangkah strategis dalam meningkatkan kinerja kepariwisataan. Peningkatan kualitas akan mendorong peningkatan jumlah kunjungan wisatawan domestik dan mancanegara yang juga akan meningkatkan penerimaan daerah terutama retribusi objek wisata dan juga akan mempengaruhi kegiatan ekonomi masyarakat sekitarnya.

\section{Potensi Aksesibilitas penerbangan, informasi)}

(transportasi,

Peningkatan jumlah kunjungan wisatawan ke Kota Banda Aceh mendorong peningkatan ketersediaan sarana dan prasarana pendukung misalnya jalan dan sarana transportasi (darat, laut, dan udara). Keberadaan jalan akses yang menghubungkan tempat-tempat kunjungan wisata menjadi faktor penunjang utama pengembangan suatu destinasi wisata, serta berperan besar dalam memberikan akses yang mudah, cepat, dan murah sehingga memperlancar perputaran roda perekonomian. Berdasarkan data BPS Kota Banda Aceh keberadaan sarana jalan akses sebagai berikut: pada tahun 2013, panjang jalan Kota Banda Aceh $707.343 \mathrm{~m}$, dimana $705.221 \mathrm{~m}$ dalam kondisi baik dan $2.122 \mathrm{~m}$ dalam kondisi rusak. Pada tahun 2014, panjang jalan Kota Banda Aceh 707.343m, dimana seluruhnya berada dalam kondisi baik. Pada tahun 2015, panjang jalan Kota Banda Aceh 707.343m, dimana $583,75 \mathrm{~m}$ dalam kondisi baik, 87,38m dalam kondisi sedang, 21,49m dalam kondisi rusak, dan 14,63m dalam kondisi rusak berat. 
Sarana transportasi sangat penting dalam menunjang kemajuan sektor pariwisata. Pertumbuhan transportasi darat di Kota Banda Aceh cukup pesat, khususnya ketika periode masuknya mahasiswa baru di beberapa universitas negeri dan swasta yang ada di wilayah Banda Aceh dan sekitarnya. Untuk itu pemerintah kota melalui Dinas Perhubungan, pada tahun 2015 mengadakan Bus Trans Koetaraja yang diperuntukkan bagi masyarakat tarif murah untuk mengurangi permasalahan yang timbul dalam bidang transportasi umum. Akan tetapi, keberadaan Bus Trans Koetaradja sebagai sarana transportasi massal belum bisa memudahkan dalam mengakses setiap destinasi wisata di Banda Aceh. Keadaan ini dapat menjadi peluang ekonomi bagi masyarakat dan pengusaha dalam menyediakan jasa transportasi yang menunjang pertumbuhan wisata syariah, dengan tidak menyebabkan permasalahan baru dalam sistem transportasi kota.

Dalam mendukung sarana transportasi darat di Kota Banda Aceh, telah tersedia satu terminal angkutan dalam kota dan dua terminal angkutan antar kota dan provinsi. Sementara jumlah angkutan umum yang tersedia terdiri atas perusahaan angkutan umum antar kota dalam provinsi (AKDP), perusahaan angkutan umum antar kota antar provinsi (AKAP) dan perusahaan angkutan umum. Berikut jumlah perusahaan angkutan umum di Kota Banda Aceh.

Tabel 3. Banyaknya perusahaan angkutan umum di Kota Banda Aceh, 2012-2015

\begin{tabular}{llcccc}
\hline No & $\begin{array}{l}\text { Perusahaan } \\
\text { Angkutan } \\
\text { Umum }\end{array}$ & $\mathbf{2 0 1 2}$ & $\mathbf{2 0 1 3}$ & $\mathbf{2 0 1 4}$ & $\mathbf{2 0 1 5}$ \\
\hline 1 & $\begin{array}{l}\text { Antar Kota } \\
\text { Dalam Provinsi } \\
\text { (AKDP) }\end{array}$ & 18 & 34 & 34 & 88 \\
\hline 2 & $\begin{array}{l}\text { Antar Kota } \\
\text { Antar Provinsi } \\
\text { (AKAP) }\end{array}$ & 6 & 8 & 8 & 19 \\
\hline 3 & Antar Kota & 4 & 4 & 4 & 4
\end{tabular}

Sumber : BPS Kota Banda Aceh, 2016
Keberadaan angkutan umum/massal di Kota Banda Aceh saat ini bukanlah andalan masyarakat, khususnya wisatawan dalam melakukan kegiatannya. Hal ini disebabkan perkembangan pelayanan yang tidak disesuaikan dengan kondisi sosial dan teknologi saat ini. Untuk itu, sarana transportasi darat yang memudahkan akses wisatawan yang menjangkau setiap destinasi yang ada di Kota Banda Aceh dan sekitarnya sangat penting untuk dikembangkan.

Transportasi laut di Kota Banda Aceh didukung dengan adanya Pelabuhan Penyeberangan Ulee Lheue. Pelabuhan ini tercatat sebagai salah satu pelabuhan terpadat di Provinsi Aceh yang menghubungkan Kota Banda Aceh dengan daerah sekitarnya. Terdapat delapan armada kapal yang tersedia, diantaranya KMP Tanjung Urang, KMP Papuyu, KMP Seumeulu, KMP Labuhan Haji, KMP BRR, KMP Pulo Rondo, KMP Express Bahari 3B, KMP Express Chantika 89.

Sementara itu untuk transportasi udara didukung dengan adanya Bandar Udara Internasional Sultan Iskandar Muda (SIM) Blang Bintang, Aceh Besar. Bandara Internasional Sultan Iskandar Muda (SIM) yang dirancang untuk kapasitas 1.700 .000 penumpang/tahun telah menjadi salah satu sarana pendukung masuknya wisatawan baik domestik maupun internasional ke Provinsi Aceh dan ke Kota Banda Aceh khususnya. Menurut BPS Provinsi Aceh (2016) tercatat lima perusahaan penerbangan nasional, yaitu Garuda Indonesia, Lion Air, Batik Air, Citilink dan Susi Air, serta terdapat dua perusahaan penerbangan asing, diantaranya Air Asia dan Fire Fly yang menjalani rute melalui Bandara Sultan Iskandar Muda. Berikut jumlah pesawat yang datang dan berangkat dalam lalu lintas penerbangan melalui Bandara Sultan Iskandar Muda.

Pengguna jasa transportasi udara melalui Bandara Sultan Iskandar Muda (SIM), terdiri atas penumpang datang dan berangkat yang berasal dari dalam dan luar negeri. Merujuk pada data BPS Aceh, jumlahnya terus meningkat setiap tahunnya. Berikut jumlah penumpang yang datang Iskandar Muda. 
Tabel 4. Jumlah Pesawat yang Datang dan Berangkat Melalui Bandar Udara Sultan Iskandar Muda, 2012-2015

\begin{tabular}{crrrrrr}
\hline Tahun & \multicolumn{3}{c}{ Datang } & & \multicolumn{3}{c}{ Berangkat } & \\
\cline { 2 - 7 } & Domestik & $\begin{array}{c}\text { Internasio } \\
\text { nal }\end{array}$ & Total & Domestik & $\begin{array}{c}\text { Internasio } \\
\text { nal }\end{array}$ & Total \\
\hline 2012 & 2.482 & 503 & 2.985 & 2.789 & 497 & 3.286 \\
\hline 2013 & 3.155 & 540 & 3.695 & 3.160 & 535 & 3.695 \\
\hline 2014 & 2.797 & 631 & 3.428 & 2.788 & 635 & 3.423 \\
\hline 2015 & 2.447 & 669 & 3.116 & 2.457 & 666 & 3.123 \\
\hline
\end{tabular}

Sumber : BPS Provinsi Aceh, 2016

Tabel 5. Jumlah Penumpang yang Datang dan Berangkat Melalui Bandar Udara Sultan Iskandar Muda, 2012-2015

\begin{tabular}{|c|c|c|c|c|c|c|}
\hline \multirow[t]{2}{*}{ Tahun } & \multicolumn{3}{|c|}{ Datang } & \multicolumn{3}{|c|}{ Berangkat } \\
\hline & Domestik & Internasional & Total & Domestik & Internasional & Total \\
\hline 2012 & 301.456 & 44.603 & 346.059 & 308.038 & 44.324 & 352.362 \\
\hline 2013 & 322.803 & 49478 & 372.281 & 338.977 & 46.910 & 385.887 \\
\hline 2014 & 330.896 & 63.442 & 394.338 & 312.051 & 69.988 & 382.039 \\
\hline 2015 & 301.339 & 70.906 & 372.245 & 312.806 & 70.155 & 382.961 \\
\hline
\end{tabular}

Sumber : BPS Provinsi Aceh, 2016

Tabel 6. Jumlah Kunjungan Wisatawan Mancanegara di Kota Banda Aceh Menurut Kawasan Negara (orang), 2012-2015

\begin{tabular}{clcccc}
\hline No & \multicolumn{1}{c}{ Kawasan } & $\mathbf{2 0 1 2}$ & $\mathbf{2 0 1 3}$ & $\mathbf{2 0 1 4}$ & $\mathbf{2 0 1 5}$ \\
\hline 1 & ASEAN & 8.530 & 11.351 & 19.817 & 21.438 \\
\hline 2 & Afrika & 26 & 30 & 30 & 46 \\
\hline 3 & Amerika & 435 & 424 & 575 & 645 \\
\hline 4 & Asia (tanpa ASEAN) & 582 & 730 & 986 & 1.309 \\
\hline 5 & Eropa & 1.812 & 1.825 & 2.276 & 2.391 \\
\hline 6 & Oseania & 336 & 438 & 503 & 446 \\
\hline 7 & Timur Tengah & 53 & 35 & 53 & 61 \\
\hline & Total & $\mathbf{1 1 . 7 7 4}$ & $\mathbf{1 4 . 8 3 3}$ & $\mathbf{2 4 . 2 4 0}$ & $\mathbf{2 6 . 3 3 6}$ \\
\hline
\end{tabular}

Sumber : BPS Kota Banda Aceh, Statistik Wisatawan Mancanegara Kota Banda Aceh (2016)

\section{Potensi Wisatawan}

Objek pariwisata suatu daerah menjadi salah satu daya tarik kunjungan wisatawan, baik wisatawan domestik dan wisatawan mancanegara untuk berkunjung ke wilayah tersebut. Berikut jumlah kunjungan wisatawan mancanegara ke Kota Banda Aceh berdasarkan kawasan negara.

Berdasarkan data jumlah kunjungan wisatawan mancanegara di Kota Banda Aceh, terdapat peningkatan jumlah total kunjungan setiap tahunnya. Pada tahun 2012 jumlah kunjungan didominasi oleh wisatawan dari kawasan Asia, sebagaimana data yang tercatat terdapat 9.112 orang atau 77,58 persen dari total kunjungan, diikuti asal Eropa 1.812 orang atau 15,38 persen, Amerika 435 orang atau 3,69 persen, Oseania 336 orang atau 2,85 persen, Timur Tengah 53 orang 0,45 persen, dan Afrika 26 orang 0,22 persen. Jumlah ini semakin meningkat di tahun 2015 dimana wisatawan yang berasal dari kawasan Asia masih mendominasi dengan jumlah 22.747 orang atau 86,37 persen dari total kunjungan wisatawan, Eropa 2.391 orang atau 9,08 persen, Amerika 645 orang atau 2,45 persen, Oseania 446 orang atau 1,7 
persen, Timur Tengah 61 orang atau 0,23persen, dan Afrika 46 orang atau 0,17 persen. Selain wisatawan mancanegara, juga terdapat wisatawan domestik yang berasal dari berbagai wilayah nusantara yang berkunjung ke Kota Banda Aceh. Merujuk dari Banda Aceh Dalam Angka, jumlah wisatawan domestik pada tahun 2013 terdapat 183.286 orang dan pada tahun 2014 terdapat 789.431 orang. Hal ini menunjukkan bahwa peningkatan jumlah kunjungan wisatawan ke Kota Banda Aceh tidak hanya pada jumlah wisatawan mancanegara tetapi juga pada jumlah wisatawan domestik.

Peningkatan kunjungan wisatawan di Kota Banda Aceh tidak terlepas dari semakin terkenalnya Provinsi Aceh melalui penerapan syariat Islam dan keberadaan situs-situs Tsunami yang menjadi daya tariknya. Selain itu, kondisi keamanan Aceh secara umum yang sudah kondusif untuk menerima wisatawan, membuat pendatang tidak lagi ragu berkunjung ke wilayah ini. Penerapan secara resmi qanun (peraturan daerah) tentang Hukum Jinayat (hukum pidana Islam) yang berlaku bagi Muslim dan nonMuslim, tidak mengkhawatirkan akan menurunkan jumlah wisatawan.

Merujuk pada Banda Aceh Dalam Angka 2016, tingkat kunjungan wisatawan nusantara sebanyak 789.431 pada tahun 2015 . Angka yang sama juga tercatat pada banyaknya kunjungan wisatawan domestik di situs pariwisata tertentu Kota Banda Aceh (Kapal di Atas Rumah Lampulo, Kapal PLTD Apung Punge Blang Cut, Makam Tgk Syiah Kuala, Konter Jubah Mesjid Raya Baiturrahman, Pusat Informasi Ulee Lheue, dan Hunian Hotel). Pengunjung objek wisata ini tidak hanya masyarakat lokal, tetapi juga datang dari beberapa daerah seperti Sumatera Utara, Sumatera Barat, Riau, Sumatera Selatan, DKI Jakarta, dan beberapa daerah lainnya di Indonesia.

Jumlah wisatawan ke Kota Banda Aceh jika dihitung dari jumlah tamu yang menginap di Hotel/akomodasi adalah sebagai berikut: jumlah kunjungan wisatawan mancanegara selama 2014 mencapai 11.103 dibandingkan 5.317 pada tahun 2013. Jumlah wisatawan domestik tahun 2014 sebanyak 224.939 dibanding tahun 2013 mencapai 229.589. Pemerintah Kota Banda Aceh telah menetapkan target untuk meningkatkan jumlah kunjungan, dimana ditargetkan wisatawan yang datang ke Banda Aceh berjumlah minimal $25 \%$ dari total wisatawan yang berkunjung ke Provinsi Aceh untuk tahun-tahun selanjutnya.

Jika dilihat secara kuantitas berdasarkan data statistik, jumlah wisatawan yang berkunjung ke Kota Banda Aceh memang mengalami peningkatan namun tidak untuk kualitas wisatawannya. Berdasarkan Length of Stay (LoS) atau lamanya wisatawan menginap, dapat dikatakan bahwa Kota Banda Aceh khususnya belum menjadi tempat tujuan wisata utama bagi para wisatawan domestik dan wisatawan mancanegara. Hal ini terlihat dari menurunnya rata-rata lama menginap wisatawan disejumlah hotel di Aceh, yakni 23 hari pada 2014 menjadi berkisar 1-2 hari pada tahun 2015. Pada tahun 2016 angka kunjungan ditargetkan meningkat, dan untuk merealisasikannya Pemerintah Kota Banda Aceh telah menyiapkan berbagai kegiatan dan atraksi wisata yang dapat menarik wisatawan untuk datang.

\section{Promosi Wisata Syariah Kota Banda Aceh}

Pengaruh globalisasi saat ini telah memunculkan banyak cara dan kesempatan baru bagi pengembangan sektor pariwisata. Wisatawan domestik dan mancanegara ingin mengeksplorasi tempat-tempat baru sebanyak mungkin. Agar keberadaan objek wisata dapat dikenal, dibutuhkan pemasaran wisata sebagai kegiatan penunjang. Pemasaran wisata adalah suatu arahan, proses, dan teknik-teknik suatu organisasi usaha pariwisata untuk memasarkan objekobjek yang ada dengan menawarkannya kepada konsumen. (Wahab, 1992).

Kegiatan pemasaran pariwisata membutuhkan konsep dan dukungan dari pemerintah maupun masyarakat lokal. Dikarenakan perkembangan strategi-strategi pemasaran yang didukung perkembangan teknologi komunikasi maka kreatifitas dalam 
melakukan promosi sangat dibutuhkan dan perlu terus untuk dikembangkan.

Untuk itu promosi wisata tidak bisa lagi hanya mengandalkan promosi konvensional, tapi juga menggunakan metode-metode dan media-media promosi yang baru. Penggunaan internet sebagai media promosi saat ini lebih representatif dan informatif, dengan menampilkan potensipotensi daerah setempat sehingga bisa menjadi rujukan utama bagi wisatawan dalam memilih destinasi.

Kota Banda Aceh melalui Dinas Pariwisata memanfaatkan beberapa media dalam melakukan promosi wisata. Kegiatan promosi melalui media cetak dan elektronik saat ini gencar dilakukan. Beberapa bentuk iklan telah disiarkan dan ditayangkan oleh Radio dan Televisi baik di dalam negeri maupun di luar negeri. Disamping radio dan televisi, bentuk promosi lain dilakukan via internet. E-marketing atau pemasaran menggunakan internet saat ini telah menjadi suatu keharusan dalam mempromosikan produk baik barang dan jasa.

\section{PEMBAHASAN}

\section{Persepsi Wisatawan Terhadap Kesiapan Kota Banda Aceh sebagai Destinasi Wisata Syariah}

Merujuk pada kajian pengembangan wisata syariah Kemenpar 2015 yang melakukan survey terhadap wisatawan, untuk mengetahui kesiapan Banda Aceh sebagai destinasi wisata syariah. Kajian ini mencakup sisi daya tarik wisata, akomodasi yang mendukung konsep wisata syariah, kesiapan destinasi. Adapun bentuk tolak ukur dari sisi daya tarik wisata syariah yang diukur antara lain ketersediaan objek wisata yang berbasis syariah, pertunjukan seni dan budaya yang tidak bertentangan dengan kaidah syariah, serta ketersediaan tempat ibadah yang layak dan suci. Tolak ukur dari sisi akomodasi pendukung antara lain penerapan konsep syariah oleh hotel/akomodasi yang ada. Sementara tolak ukur dari sisi kesiapan destinasi antara lain kesiapan sarana pendukung lain seperti restoran/rumah makan, spa, agen wisata yang menerapkan konsep syariah dalam kegiatan pelayanannya.

Pada kajian pertama, persepsi wisatawan menyatakan bahwa kondisi DTW Banda Aceh cukup baik, dimana objek wisata yang ada sudah menjalani konsep syariah. Disamping itu penyelenggaraan pertunjukan seni dan budaya telah dilaksanakan sesuai dengan kaidah syariah dengan adanya pengawasan dari Wilayatul Hisbah yaitu sebuah lembaga yang melakukan pengawasan pelaksanaan syariat Islam di daerah setempat. Dan untuk ketersediaan tempat ibadah, wisatawan berpersepsi keberadaannya sudah sangat baik.

Pada kajian kedua, persepsi wisatawan menyatakan bahwa dari sisi akomodasi pendukung, dalam hal ini keberadaan hotel/penginapan. Responden berpendapat positif tentang fasilitas perhotelan di Kota Banda Aceh. Kategori yang ditetapkan telah memenuhi diantaranya tersedia tempat ibadah yang layak di hotel dan tempat menginap lainnya, tersedia sarana bersuci yang layak di hotel dan tempat menginap lainnya, tersedia makanan dan minuman halal di hotel dan tempat menginap lainnya, suasana hotel nyaman dan kondusif untuk keluarga dan keperluan bisnis, sanitasi dan kebersihan lingkungan hotel terjaga dengan baik.

Pada kajian ketiga tentang kesiapan destinasi seperti kesiapan restoran/rumah makan, spa, agen wisata yang berkonsep syariah. Dalam hal ini responden berpendapat positif dimana terdapat restoran/rumah makan yang menyediakan makanan dan minuman yang terjamin kehalalannya dengan sertifikat halal MUI, terjaminnya sanitasi dan kebersihan lingkungan restoran. Konsep halal dalam konteks ini mengacu pada nilai-nilai dan etika syariah dalam Islam, dimana halal artinya dibenarkan dan haram artinya dilarang. Jaminan kehalalan produk akan meningkatkan nilainya yang berupa intangible value, produk yang kemasannya tercantum label halal akan lebih menarik bagi konsumen muslim (Hamzah \& Yudiana, 2015). Sementara untuk fasilitas Spa dan Sauna juga memperoleh respon 
positif, dimana praktik spa dan sauna memisahkan antara pelanggan pria dan wanita serta ditangani oleh terapis sejenis,

menggunakan bahan yang halal, tersedia sarana yang memudahkan untuk beribadah di tempat spa dan sauna.

\section{Dampak Pariwisata Terhadap Sektor PerekonomianKota Banda Aceh}

Pariwisata pada dasarnya adalah melakukan perjalanan untuk tujuan dan maksud tertentu dalam memenuhi kebutuhan, baik psikologis maupun fisik. Marpaung (2002) menyatakan bahwa wisatawan melakukan aktivitas selama mereka tinggal di tempat yang dituju dan mengusahakan fasilitas yang ada untuk memenuhi kebutuhan mereka.

Sektor Pariwisata dapat menjadi sektor potensial untuk dikembangkan sebagai sumber pendapatan ekonomi masyarakat. Pemberdayaan sektor pariwisata secara maksimal dengan pendayagunaan sumber daya dan potensi daerah yang ada semestinya dapat mendorong pertumbuhan ekonomi. Kegiatan wisata sejatinya menciptakan permintaan baik untuk konsumsi maupun investasi yang akhirnya akan mendorong kegiatan produksi atas barang dan jasa. Wardiyanta (2006) menyebutkan sektor pariwisata mempunyai sifat yang khas, karena tidak hanya melibatkan banyak industri, seperti transportasi, akomodasi, jasa boga, atraksi, retai, tetapi juga menyerap banyak tenaga kerja.

Petters dan Bryden dalam (Soekadijo: 1997), merumuskan lima dampak positif pengembangan pariwisata yang dijadikan tujuan pengembangan pariwisata sebagai berikut: (1) Menyumbang kepada neraca pembayaran, (2) Menyebarkan pembangunan ke daerah-daerah yang non industri, (3) Menciptakan kesempatan kerja, (4) Dampak pada pembangunan ekonomi pada umumnya melalui dampak pengganda (multiplier effect), dan (5) Keterkaitan sektor pariwisata dengan sektor lain dalam perekonomian.

Spillane (1994) menyebutkan bahwa wisatawan akan melakukan perbelanjaan yang menimbulkan permintaan (Tourism
Final Demand) pasar barang dan jasa. Selanjutnya final demand wisatawan akan menimbulkan permintaan akan barang modal dan bahan baku (Investment Derived Demand) untuk berproduksi memenuhi permintaan wisatawan akan barang tersebut. Dalam usaha memenuhi permintaan wisatawan diperlukan investasi di bidang transportasi dan komunikasi, perhotelan dan akomodasi lain, industri kerajinan dan industri produk konsumen, industri jasa, rumah makan/restoran dan lain-lain.

Berdasarkan data statistik Kota Banda Aceh terdapat peningkatan ketersediaan sarana dan prasana pendukung sektor pariwisata, diantaranya perhotelan, agen perjalanan wisata, serta rumah makan/restoran.

Tabel 7. Jumlah Hotel Menurut Klasifikasi di Kota Banda Aceh, 2012 - 2015

\begin{tabular}{clcccc}
\hline No & Klasifikasi & $\mathbf{2 0 1 2}$ & $\mathbf{2 0 1 3}$ & $\mathbf{2 0 1 4}$ & $\mathbf{2 0 1 5}$ \\
\hline 1 & Bintang 5 & 0 & 0 & 0 & 0 \\
\hline 2 & Bintang 4 & 1 & 1 & 1 & 1 \\
\hline 3 & Bintang 3 & 2 & 3 & 5 & 6 \\
\hline 4 & Bintang 2 & 3 & 2 & 0 & 2 \\
\hline 5 & Bintang 1 & 10 & 11 & 3 & 1 \\
\hline 6 & Melati & 32 & 32 & 42 & 41 \\
\hline & Jumlah & 48 & 49 & 51 & 51 \\
\hline
\end{tabular}

Sumber : BPS Kota Banda Aceh, Banda Aceh Dalam Angka (2016)

Jumlah hotel dan tempat menginap di Kota Banda Aceh diklasifikasikan dari hotel kelas melati hingga hotel bintang lima. Merujuk pada data Banda Aceh Dalam Angka tahun 2015, terdapat peningkatan jumlah hotel di Kota Banda Aceh, yaitu sebanyak 48 hotel pada tahun 2012, 49 hotel pada tahun 2013, 51 hotel di tahun 2014 dan 51 hotel pada tahun 2015. Sesuai dengan penerapan syariat Islam di Aceh, maka setiap hotel dan penginapan harus menjalankan aktivitasnya berbasis syariah. Menurut pasal 1 Peraturan Menteri Pariwisata dan Ekonomi Kreatif Indonesia No. 2 tahun 2014 tentang pedoman penyelenggaraan hotel syariah, yang dimaksud syariah disini adalah sesuai dengan prinsip-prinsip hukum Islam sebagaimana diatur fatwa Majelis Ulama Indonesia. 
Dalam hal ini hotel yang mengusung prinsip syariah tidak melayani minuman beralkohol dan memiliki kolam renang dan fasilitas terpisah untuk pria dan wanita (Wuryasti, 2013).

Selain hotel dan penginapan, pendukung sektor wisata syariah lainnya setiap tahunnya. Dalam konteks syariah, biro perjalanan wisata harus menyediakan paket perjalanan/wisata yang sesuai dengan kriteria pariwisata syariah, memiliki daftar akomodasi yang sesuai dengan panduan umum akomodasi pariwisata syariah, memiliki daftar usaha penyedia makanan dan minuman yang sesuai dengan panduan umum usaha penyedia makanan dan minuman pariwisata syariah (Kemenpar, 2014).

Kategori rumah makan/restoran dalam konteks pariwisata syariah harus memenuhi indicator yang terjamin kehalalan makanan dan minuman dengan sertifikat halal MUI, terjaga lingkungan yang sehat dan bersih (Kemenpar, 2014). Berdasarkan data BPS Kota Banda Aceh, jumlah rumah makan/restoran dapat dilihat dari tabel 8. adalah biro perjalanan dan rumah makan/restoran. Berdasarkan BPS Kota Banda Aceh jumlah biro perjalanan dan pariwisata di Kota Banda Aceh pada tahun 2012 terdapat 52 agen, tahun 2013 terdapat 80 agen, dan tahun 2014 terdapat 97 agen, kondisi ini menunjukkan peningkatan jumlah

Tabel 8. Jumlah rumah makan, cafe dan restoran di Kota Banda Aceh, 2012-2014

\begin{tabular}{clrrr}
\hline No & \multicolumn{1}{c}{ Tahun } & 2012 & 2013 & 2014 \\
\hline 1 & $\begin{array}{l}\text { Restoran/rumah } \\
\text { makan }\end{array}$ & 102 & 106 & 241 \\
\hline 2 & Kedai kopi & 170 & 170 & 4 \\
\hline 3 & Warung kopi & 92 & 92 & 2 \\
\hline 4 & Café & 35 & 37 & 226
\end{tabular}

Sumber : BPS Kota Banda Aceh, 2015

Secara umum sumbangan sektor pariwisata jika ditinjau dari keberadaan hotel, restoran, hiburan dan rekreasi terhadap perekonomian dapat dilihat dari Struktur PDRB Atas Dasar Harga Berlaku Kota Banda Aceh.

Tabel 9. Produk Domestik Regional Bruto Atas Dasar Harga Berlaku Kota Banda Aceh (Juta Rupiah), 20122015

\begin{tabular}{|c|c|c|c|c|c|}
\hline No & Kategori & 2012 & 2013 & $2014 *$ & $2015 * *$ \\
\hline A & Pertanian, Kehutanan, dan Perikanan & $117.403,2$ & $126.329,3$ & $135.264,6$ & $142.201,5$ \\
\hline B & Pertambangan dan Penggalian & 0,0 & 0,0 & 0,0 & 0,0 \\
\hline $\mathrm{C}$ & Industri Pengolahan & $242.273,7$ & $262.640,8$ & $283.696,6$ & $299.660,1$ \\
\hline $\mathrm{D}$ & Pengadaan Listrik dan Gas & $32.100,0$ & $32.502,3$ & $35.781,5$ & $36.657,9$ \\
\hline $\mathrm{E}$ & $\begin{array}{l}\text { Pengadaan Air, Pengelolaan Sampah, } \\
\text { Limbah dan Daur Ulang }\end{array}$ & $9.161,2$ & $10.440,7$ & $11.639,5$ & $13.898,8$ \\
\hline $\mathrm{F}$ & Konstruksi & $934.143,9$ & $958.082,6$ & $960.238,1$ & $1.103 .743,6$ \\
\hline G & $\begin{array}{l}\text { Perdagangan Besar dan Eceran; } \\
\text { Reparasi Mobil dan Sepeda Motor }\end{array}$ & $2.619 .273,1$ & $2.827 .199,8$ & $3.059 .382,8$ & $3.223 .290,0$ \\
\hline $\mathrm{H}$ & Transportasi dan Pergudangan & $1.833 .820,2$ & $1.948 .671,9$ & $2.072 .370,4$ & $2.116 .684,7$ \\
\hline I & $\begin{array}{l}\text { Penyediaan Akomodasi dan Makan } \\
\text { Minum }\end{array}$ & $285.854,9$ & $331.148,8$ & $382.551,5$ & $432.808,4$ \\
\hline $\mathrm{J}$ & Informasi dan Komunikasi & $900.348,5$ & $942.579,2$ & $999.810,2$ & $1.073 .443,1$ \\
\hline $\mathrm{K}$ & Jasa Keuangan dan Asuransi & $328.004,7$ & $389.608,8$ & $395.006,6$ & $423.800,0$ \\
\hline $\mathrm{L}$ & Real Estate & $608.221,2$ & $700.447,4$ & $830.077,6$ & $970.979,0$ \\
\hline M,N & Jasa Perusahaan & $260.880,5$ & $288.493,0$ & $321.106,6$ & $338.943,9$ \\
\hline $\mathrm{O}$ & $\begin{array}{l}\text { Administrasi Pemerintahan, Pertahanan } \\
\text { dan Jaminan Sosial Wajib }\end{array}$ & $2.225 .309,3$ & $2.456 .331,4$ & $2.730 .681,1$ & $3.001 .088,0$ \\
\hline $\mathrm{P}$ & Jasa Pendidikan & $606.128,9$ & $659.443,4$ & $715.857,0$ & $777.814,8$ \\
\hline Q & Jasa Kesehatan dan Kegiatan Sosial & $387.603,7$ & $432.781,4$ & $488.777,1$ & $540.726,2$ \\
\hline $\mathrm{R}, \mathrm{S}, \mathrm{T}$ & Jasa Lainnya & $183.399,6$ & $201.303,2$ & $225.282,7$ & $246.129,5$ \\
\hline & PDRB & $11.573 .926,8$ & 12.568.004,0 & 13.647.523,9 & 14.741.869,5 \\
\hline
\end{tabular}

Sumber : Badan Pusat Statistik Kota Banda Aceh, 2016 
Berdasarkan tabel 9, sumbangan sektor pariwisata jika dilihat dari kontribusi hotel dan restoran dalam kategori penyedia akomodasi dan makan minum tidak terlalu besar namun terjadi peningkatan.Pada tahun 2012 sumbangan kategori ini terhadap PDRB Kota Banda Aceh sebesar 2,24 persen, tahun 2013 sebesar 2,63 persen, tahun 2014 sebesar 2,80 persen, dan pada tahun 2015 sebesar 2,87 persen.

Kondisi ini jika semakin didorong akan mendatangkan dampak positif bagi pendapatan daerah, dengan mewujudkan peningkatan kesejahteraan rakyat melalui perluasan dan pemerataan kesempatan berusaha dan lapangan kerja di sektor pariwisata serta pengembangan sarana dan prasarana pendukung dengan tidak mengenyampingkan nilai-nilai syariahsebagai nilai jual Kota Banda Aceh.

\section{KESIMPULAN}

Perkembangan sektor pariwisata berbasis syariah di Kota Banda Aceh semakin meningkat, hal ini ditandai dengan adanya peningkatan sumbangan sektor pariwisata terhadap sektor ekonomi daerah yang dapat dilihat dari struktur PDRB Kota Banda Aceh. Untuk itu unsur-unsur terkait, dalam hal ini pemerintah daerah, pengusaha dan masyarakat harus bekerja lebih maksimal dalam mengoptimalkan keberadaan sektor pariwisata tersebut.Kerjasama yang sinergis dibutuhkan untuk mewujudkan manajemen kepariwisataan yang baik pada seluruh bidang pendukung, yang pada gilirannya akan meningkatkan pendapatan asli daerah dan berkontribusi pula terhadap peningkatan devisa negara.

Kota Banda Aceh harus memiliki agenda yang jelas dan terarah terkait peningkatan mutu pelayanan wisata berbasis syariah. Optimalisasi hendaknya dilakukan dalam segala aspek pendukung penerapan wisata syariah, seperti subsektor restoran/rumah makan, hotel/penginapan, dan agen perjalanan. Setiap wisatawan berhak memperoleh kenyamanan dan jaminan atas kegiatannya, dengan komitmen keutamaan konsep halal atas seluruh sektor pendukung wisata syariah, khususnya di Kota Banda Aceh. Hal ini bertujuan untuk mewujudkan Kota Banda Aceh sebagai kota madani sekaligus destinasi wisata islami dunia.

\section{DAFTAR PUSTAKA}

Banda AcehTourism. (2015). Ide Membangun Masyarakat Sadar Wisata. Dipetik Oktober 30, 2016, dari http://www.bandaacehtourism.com/bu daya/sosok/ide-membangunmasyarakat-sadarwisata/\#.WIHRSv197IU

Bappeda Kota Banda Aceh. (2016). Tinjauan Perekonomian Kota Banda Aceh 2015. Aceh : Bappeda Kota Banda Aceh

BPS Kota Banda Aceh. (2016). Kota Banda Aceh Dalam Angka 2016. Aceh: BPS Provinsi Aceh.

BPSProvAceh. (2016). Provinsi Aceh Dalam Angka 2015. Aceh: BPS Provinsi Aceh.

Hamzah, Maulana.M., \&Yudiana, Yudi. (2015, Februari 9). Analisis Komparatif Potensi Industri Halal dalam Wisata Syariah dengan Konvensional. Dipetik Desember 8, 2016, dari http://catatanek18.blogspot.co.id:http://catatanek18.blogspot.co.id/2015/02/analisiskomparatif-potensi-industri.html

Indonesia, Serambi. (2016, Desember 8). Banda Aceh Menuju Wisata Halal Dunia. Dipetik Desember 15, 2016, dari

http://aceh.tribunnews.com/2016/12/0 8/banda-aceh-menuju-wisata-halaldunia

Kemenpar. (2012, Desember 20). Kemenparekraf Promosikan Indonesia Sebagai Destinasi Pariwisata Syariah Dunia. Dipetik Oktober 2016, 12, dari http://www.kemenpar.go.id:

http://www.kemenpar.go.id/asp/detil.a $\mathrm{sp} ? \mathrm{c}=16 \& \mathrm{id}=2042$ 
KomunitasIloveAceh. (2012). Banda Aceh Tourism Map. Dipetik Desember 14, 2016, dari http://iloveaceh.tumblr.com/post/501 6479935/banda-aceh-tourism-mapvisitbandaaceh

Marpaung, Happy. 2002. Pengetahuan Kepariwisataan. Alfabeta. Bandung

Pendit, N.S. 1999. Ilmu Pariwisata Sebuah Pengantar Perdana. PT.Anem Kosong Anem

Republik Indonesia. 1999. Undang-undang no.10 Tentang Kepariwisataan

Soekadijo.1997. Anatomi Pariwisata (Memahami Pariwisata sebagai Sistem Linkage). Gramedia Pustaka Utama. Jakarta

Spillane, J James. 1994. Pariwisata Indonesia Siasat Ekonomi dan Rekayasa Kebudayaan. Kanisius. Yogyakarta
Sudemen, I Wayan. 2009. Peranan Sektor Pariwisata Terhadap Perekonomian Provinsi Bali. Dalam Jurnal Sarathi, 16(3): h:394-403.

Warsidi, Adi. (2015, Mei 16). Wisata Syariah Aceh Tahun Ini Targetkan 1,8 Juta Turis. Dipetik November 5, 2016, dari

http://nasional.tempo.co/read/news/2 015/05/16/058666645/ wisatasyariah-aceh-tahun-ini-targetkan-18 -juta-turis

Wuryasti, Fetri. (2013, Oktober 30). Wisata Halal, Konsep Baru Kegiatan Wisata di Indonesia. Dipetik November1, 2016 , dari http://travel.detik.com/read/2013/10/ 30/152010/2399509/1382/ wisatahalal-konsep-baru-kegiatan-wisatadi-indonesia

Yoeti, Oka A. 1996. Pengantar Ilmu Pariwisata. PT.Angkasa. Bandung 